\title{
Preditores e Impactos da Legitimidade Policial: Testando a Teoria da Justeza Procedimental em São Paulo*
}

\author{
Thiago R. Oliveira ${ }^{1}$ \\ André Zanetic ${ }^{2}$ \\ Ariadne Natal ${ }^{3}$ \\ ${ }^{1}$ Doutorando em Social Research Methods na London School of Economics and Political Science, \\ Londres, Reino Unido e pesquisador associado ao Núcleo de Estudos da Violência da Universidade \\ de São Paulo (NEV-USP), São Paulo - SP, Brasil. \\ E-mail: t.rodrigues-oliveira@lse.ac.uk, http://orcid.org/0000-0002-3235-8686 \\ 2Professor Visitante do Programa de Pós-Graduação em Sociologia da Universidade Federal da Grande \\ Dourados (PPGS/UFGD), Grande Dourados - MS, Brasil. \\ E-mail: andrezanetic@gmail.com, https:/ / orcid.org/0000-0003-4165-7343?lang=en \\ ${ }^{3}$ Pesquisadora do Núcleo de Estudos da Violência da Universidade de São Paulo (NEV-USP), São Paulo - \\ SP, Brasil. \\ E-mail: ariadnenatal@gmail.com, https:/ / orcid.org/0000-0002-5925-043X
}

\section{INTRODUÇÃO}

Quando os cidadãos reconhecem a autoridade como legítima, internalizando as normas sociais e consentindo livremente com seus comandos, eles tendem a se comportar de modo respeitoso às leis, obedecendo-as voluntariamente. Essa é parte da hipótese lançada por Tom Tyler (1990) a respeito do efeito de uma autoridade legítima para sociedades democráticas: em vez de coerção ou resignação, uma obediência que se caracterize por ser normativamente fundamentada e o comportamento de deferência às leis. $E$ a melhor estratégia da autoridade para que the seja conferida legitimidade, ainda de acordo com Tyler, envolve o modo como seus agentes se comportam durante os encontros com os cidadãos: sendo tratados com respeito e impar-

\footnotetext{
"Este artigo foi realizado como parte projeto do Centro de Pesquisa, Ensino e Difusão da Fundação de Amparo à Pesquisa do Estado de São Paulo (Cepid-Fapesp 2013-079237) "Building Democracy Daily: Human Rights, Violence and Institutional Trust", desenvolvido no Núcleo de Estudos da Violência da Universidade de São Paulo (NEV-USP). Agradecemos ao apoio da Fapesp para a realização deste trabalho. Também agradecemos a colegas do NEV-USP por sua atenciosa leitura de versões preliminares deste artigo.
}

DADOS, Rio de Janeiro, vol.63(1): e20170159, 2020. 
cialidade e reconhecendo decisões tomadas com alta qualidade, os indivíduos tendem a perceber a autoridade como legítima.

As afirmações acima resumem a chamada teoria da justeza procedimental, desenvolvida originalmente por Tyler e testada por uma série de pesquisas realizadas em diversos países (Sunshine e Tyler, 2003; Hinds e Murphy, 2007; Jackson et al., 2012a). Apesar de se referir à autoridade estatal de uma maneira geral, essa literatura criminológica tem se concentrado na atuação da força policial, dado que ela consiste no principal órgão ao qual cabe a efetivação do monopólio estatal do uso da força. Assim, a problemática refere-se justamente aos modos como os policiais devem agir para que se aumente a percepção de legitimidade policial por parte dos cidadãos, bem como se essa percepção de legitimidade efetivamente gera comportamentos de respeito às leis.

O objetivo deste artigo é discutir os resultados de um teste da teoria da justeza procedimental e da legitimidade policial no contexto brasileiro. Para tanto, foi realizado não apenas o teste do modelo geral desenvolvido por Tyler a respeito da legitimidade policial nesse contexto marcado por relações entre cidadãos e polícia bastante particulares, tal qual as mais recentes configurações que esse modelo adquiriu, como foi testado também um modelo em que foi utilizada uma nova configuração da variável "obediência às leis", através da categorização de respostas espontâneas, de forma a melhor captar os impactos das conflituosas relações entre polícia e indivíduos sobre essa propensão à obediência.

Nesse sentido, este artigo dá continuidade a um trabalho prévio desenvolvido por Zanetic et al. (2016), que buscou introduzir conceitualmente a teoria da legitimidade como um contraponto ao modelo de policiamento preconizado pela teoria da dissuasão; bem como discute com outro trabalho desenvolvido no sentido de analisar relações entre práticas institucionais policiais relacionadas à justeza procedimental, confiança na polícia e legitimidade das leis no contexto paulistano, que já havia apontado algumas limitações da mensuração de atributos presentes na teoria da legitimidade e da justeza procedimental, em especial no contexto brasileiro (Zanetic et al., 2016).

Utilizando dados de um survey representativo de moradores adultos da cidade de São Paulo em 2015, desenvolvido por pesquisadores do Núcleo de Estudos da Violência da Universidade de São Paulo, 
adotamos uma abordagem reflexiva para mensurar variáveis latentes e utilizamos modelos de equações estruturais para investigar a associação entre percepções de justeza procedimental e de eficácia policial e julgamentos sobre a legitimidade da polícia, bem como entre legitimidade policial e o comportamento de respeito às leis. As medidas que utilizamos foram baseadas em estudos anteriores desenvolvidos por Sunshine e Tyler (2003), Jackson et al. (2012a), entre outros.

O artigo é dividido da seguinte maneira. Em um primeiro momento, fazemos a discussão conceitual sobre legitimidade policial. Iniciando pelas definições conceituais de legitimidade da autoridade a partir de Weber (2004) e Beetham (1991), discutimos também o papel das instituições de segurança e justiça na garantia de um comportamento de respeito às leis, contrapondo o modelo dissuasório tradicionalmente adotado pelas políticas de segurança pública no Brasil ao modelo da justeza procedimental e da obediência normativa proposto por Tyler. Aqui também apresentamos a literatura, demonstrando os diversos testes empíricos dessa teoria em diversas localidades e as distintas formas adotadas para mensurar legitimidade policial. Por fim, contextualizamos as relações entre cidadãos e polícia no Brasil e em São Paulo.

Em um segundo momento, introduzimos os elementos da pesquisa empírica desenvolvida, apresentando os dados e medidas e a estratégia analítica adotada - que envolveu três etapas: um primeiro teste da teoria da justeza procedimental; uma análise de conteúdo das respostas espontâneas concernentes à motivação para obediência dos cidadãos, a qual gerou quatro categorias de disposição a obedecer à polícia; e um segundo teste da teoria da justeza procedimental, agora com a inserção das quatro categorias criadas. Os resultados das três etapas são discutidos a seguir, bem como possíveis implicações deste estudo para as políticas de segurança pública em contexto brasileiro.

\section{LEGITIMIDADE POLICIAL}

Por que as pessoas obedecem às leis?

Segundo Tyler (1990), o comportamento de deferência às leis e às autoridades pode ser motivado tanto por razões instrumentais quanto normativas. De um lado, as razões instrumentais envolveriam um cálculo racional e pragmático, por parte dos indivíduos, que leva em 
conta os ganhos e as perdas pessoais em cada ação e a capacidade das instituições em prevenir o crime por meio da eficácia com que aplica métodos ostensivos, de maneira que a obediência se basearia mais na resignação e no medo do que no reconhecimento da autoridade. Em contraposição, Tyler investiga a influência de um modelo de regulação no qual a obediência se daria por razões positivas, de maneira que a aquiescência não seria baseada na eficácia ou na capacidade das instituições em impor controle, mas, sim, em uma forma de consentimento e comprometimento voluntário com as ações da autoridade, um modelo que se basearia na legitimação da autoridade.

Desse modo, para além dos motivos instrumentais baseados em sistemas de sanções e benefícios, seria necessário pensar a obediência às leis por motivação normativa. Esse seria um modelo vantajoso por várias motivos, pois quando podem contar que a maior parte da população vai respeitar as leis, então as autoridades minimizariam os esforços e recursos alocados nos sistemas de monitoramento e controle e concentrariam seus escassos recursos nos problemas considerados realmente graves. Esse seria também um caminho com maiores chances de estabilidade ao longo do tempo, visto que o apoio público às autoridades e instituições não estaria condicionado ao seu desempenho ou demonstrações de força, sendo, portanto, menos afetados por circunstâncias ou situações de crise.

Nesse sentido, a legitimidade aparece como um conceito-chave para pensar como garantir respeito às leis por razões normativas. A legitimidade da autoridade é vital para instituições e autoridades na medida em que ela justifica o exercício de poder e garante maior adesão voluntária da população. Embora as definições de legitimidade possam variar substancialmente, uma ideia central para vários autores é a de que legitimidade envolve o reconhecimento de uma autoridade e de seu direito a emitir comandos e o consequente dever de obedecer (Beetham, 1991; Coicaud, 2002; Bottoms e Tanbeke, 2012). Segundo Beetham (1991), a legitimidade é constituída por três dimensões: consentimento (reconhecimento do direito da autoridade de exercer poder), legalidade (poderes prescritos de acordo com normas e valores sociais) e valores compartilhados (convergência entre objetivos e valores entre as autoridades e aqueles que a elas se submetem).

Segundo o modelo regulatório de legitimidade proposto por Tyler, o melhor caminho para garantir o respeito à lei e a cooperação com 
as autoridades seria a internalização de valores que são percebidos pelos indivíduos como uma motivação própria e imperativa, uma obrigação motivada por um senso de responsabilidade. As origens dessa abordagem de legitimidade remontam a Weber (2004), segundo o qual a habilidade que uma autoridade tem para garantir obediência aos seus comandos não se funda apenas na força, mas na crença de possessão de características distintivas que garantiriam sua legitimidade. Também Durkheim (1999), Freud (2011) e Elias (1997) tratam em alguma medida de processos de internalização de normas e valores sociais, inicialmente externas e até mesmo conflitantes com interesses e impulsos individuais, mas que eventualmente se tornam parte das motivações internas dos sujeitos e guiam suas escolhas e comportamentos sem depender constantemente de um sistema de vigilância, incentivos e sanções.

No entanto, no modelo da legitimidade tal qual proposto por Tyler, a motivação para obedecer não está na coerção, no constrangimento social, na culpa ou nos valores morais individuais, mas na percepção de que a autoridade é legítima. Essa distinção é importante, pois embora a moralidade e o entendimento do certo e errado sejam construções socialmente compartilhadas, em sociedades diversas e complexas nós lidamos com percepções que variam entre distintos grupos e contextos (Hitlin e Vaisey, 2013), o que aumenta o desafio para o exercício da autoridade e obtenção de cooperação e obediência. Dessa forma, segundo o modelo proposto por Tyler, uma autoridade considerada legítima tem o poder de determinar o que são comportamentos apropriados e obtém consentimento e adesão a despeito da diversidade de posicionamentos, considerações morais e interesses pessoais (Tyler, 2003).

\section{O papel das instituições de segurança e justiça}

Todas as organizações humanas possuem mecanismos de controle social com o objetivo de garantir respeito às regras, normas ou leis. Nas sociedades contemporâneas esse papel tem sido desempenhado sobretudo pelas instituições de segurança e justiça, concebidas com o objetivo de mediar disputas, corrigir desvios de conduta e enfrentar o desafio de aumentar a disposição dos cidadãos para respeitar as leis (Sunshine e Tyler, 2003). Em particular, a instituição policial assume protagonismo, dado que a polícia consiste no braço do Estado ao qual o monopólio do uso da força é delegado. 
Para além do debate a respeito dos preditores de desvios e transgressões de comportamento em âmbito individual ou mesmo psicológico, interessa-nos aqui o papel que o Estado, e em especial a polícia, exerce no estímulo do comportamento de deferência às leis e às autoridades. Destarte, algumas questões iniciais merecem nossa atenção: em que medida as pessoas respeitam as leis e as autoridades motivadas pelo receio de sofrer sanção e em que medida essa disposição está baseada na percepção de que respeitar é a coisa certa a se fazer? Que estratégias têm sido adotadas pelas instituições responsáveis por estimular o respeito às leis e às autoridades e que tipo de resultado elas têm obtido?

Como discutido acima, há duas razões principais para a obediência às leis: as instrumentais e as normativas. Assim, o trabalho cotidiano das instituições policiais busca que os cidadãos tenham um comportamento de respeito às normas e leis enfatizando uma dessas motivações. Tradicionalmente, a principal estratégia adotada por instituições de segurança e justiça ocidentais para assegurar o respeito à lei tem se baseado no modelo preconizado pela teoria da dissuasão, isto é, tem buscado que os cidadãos obedeçam às autoridades por razões instrumentais. Segundo esse modelo, a probabilidade de um crime acontecer varia em função da punição aplicada, de maneira que maximizar a certeza e a severidade da punição seria o caminho mais adequado para desencorajar a ocorrência de delitos (Kennedy, 1984; Fagan e Meares, 2008). Dessa forma, aumentar as ameaças de punição contra um determinado crime seria a melhor estratégia para coibi-lo, pois, quanto mais vigilância e punição, menos crimes.

Sob a perspectiva da gestão pública, a consequência direta dessa abordagem é um sistema de segurança e justiça criminal que sinalize a um potencial criminoso que seus riscos não compensam os possíveis ganhos da carreira infracional, de maneira que a obediência às leis seria assegurada pelo risco crível de sanções severas. Trata-se, portanto, de uma obediência instrumental, pois as pessoas respeitariam às leis e às autoridades em razão do receio do que pode acontecer se não as respeitassem (Jackson et al., 2012b).

Uma das características de um policiamento que segue o modelo dissuasório é a valorização de indicadores da "eficácia policial" apresentados como números de apreensões e prisões, em detrimento de questões como vitimização, percepção da população a respeito de medo, insegurança ou mesmo a qualidade do tratamento dos poli- 
ciais. No contexto brasileiro, embora os estudos que buscaram testar a hipótese da teoria da dissuasão tenham sido, no mínimo, inconclusivos, grande parte do repertório das estratégias de segurança pública propostas e implementadas como soluções para problemas de segurança estão calcadas nessa teoria (Zanetic et al., 2016).

Entretanto, em se tratando de sociedades democráticas, basear o sistema legal e o trabalho da polícia em monitoramento, vigilância e coerção, além de ser custoso, na medida em que cria um sistema que demanda recursos e expansão constante, também pode ser criticável, pois envolve maior ênfase na intrusão, o que pode aumentar o distanciamento entre a autoridade e a sociedade, desestimulando a participação e a cooperação ou até mesmo gerando resistências e questionamento por parte da sociedade. Em uma democracia a solução policial deve ser sempre finita, pontual e provisória, de maneira que a ordem pública não pode se sustentar na coerção, pois ela não é uma solução em si, mas sim um recurso temporário (Muniz e Proença Jr., 2014).

\section{Justeza procedimental e obediência normativa}

Em pesquisas realizadas sobretudo em países anglo-saxões, Tom Tyler e outros pesquisadores inspirados em seus estudos têm apontado os limites do modelo dissuasório e propõem explorar outros elementos que podem ter impacto na disposição dos cidadãos em respeitar às leis. Suas pesquisas investigam a hipótese de que o respeito às leis pode estar mais relacionado com o reconhecimento da autoridade como legítima do que com a coerção e o receio de ser punido (Tyler, 1990, 2004; Sunshine e Tyler, 2003). Isto não significa dizer que as práticas ligadas à teoria da dissuasão sejam ineficazes ou não cumpram o papel de estimular o respeito à lei, mas indicam a importância de considerarmos que sua contribuição pode ser limitada, além de apontar a necessidade de verificarmos outros caminhos que contribuam para o resultado almejado.

Nesse sentido, foi estabelecida a proposta de se investigar a validade de um modelo regulatório baseado em razões normativas, lançando a hipótese de que a legitimidade das leis - e da polícia, em particular - é um elemento fundamental para assegurar o respeito às leis. Assim, uma questão ulterior passa a ser compreender em que condições a legitimidade pode ser conquistada e mantida e que estratégias as instituições podem adotar para estimulá-la. 
Outrossim, Tyler argumenta que o julgamento que as pessoas fazem a respeito da forma como as leis são aplicadas e como a autoridade age no cotidiano são elementos fundamentais para assegurar a legitimidade. É o que ele chama de "justeza procedimental" (procedural justice, no original), um conceito que faz referência à qualidade do processo decisório e do tratamento interpessoal, levando em conta a existência dos seguintes elementos: a) participação nas decisões, ou seja, se as pessoas envolvidas são ouvidas e seus pontos de vista considerados; b) neutralidade, que envolve decisões objetivas baseadas em fatos, sem viés pessoal, discriminação ou favorecimento de grupos específicos; c) transparência com relação aos procedimentos e decisões tomadas; d) qualidade do tratamento interpessoal, o que envolve, educação, dignidade, respeito e cortesia; e) confiança nas intenções das autoridades e que suas decisões levam em consideração o bem-estar e a necessidade daqueles que são afetados (Sunshine e Tyler, 2003; Tyler, 2004, 2009).

A expectativa de que as instituições ajam com justeza procedimental criaria envolvimento e estimularia sentimentos de responsabilidade que levariam à legitimação por meio de um senso de obrigação em obedecer, pois quando agem de maneira justa, as autoridades fundamentam o direito de exercer o poder. Para se estabelecer, manter e se reproduzir, todas as instituições precisam se legitimar, de maneira que a legitimidade também é a base do poder da polícia. Uma força policial legítima seria aquela que é obedecida não por medo, mas porque exerce o poder de maneira adequada. De acordo com as dimensões propostas por Beetham, a legitimidade da polícia seria, portanto, a percepção de que a polícia age de acordo com certas regras, que são justas e justificáveis e que gera consentimento do público (Jackson e Bradford, 2010).

O modelo de Tyler contrapõe essencialmente os meios e os fins do trabalho policial. De acordo com esse autor, o que faz com que a população confira legitimidade à instituição policial não é uma avaliação positiva do trabalho realizado pelos policiais, isto é, não é a eficácia policial; mas a avaliação positiva do tratamento recebido pelos oficiais. Havendo justeza nos procedimentos cotidianos e nas interações entre cidadãos e policiais, maior a percepção de legitimidade.

Em linhas gerais, o modelo explicativo proposto por Tyler investiga em que medida a percepção de justeza procedimental promove legitimidade e, em um segundo momento, qual o impacto da legitimidade para disposição em 
respeitar as leis ${ }^{1}$. Esse modelo, portanto, envolveria duas hipóteses, resumidas no caminho superior da Figura 1.

Figura 1

Modelo de regulação social: razões normativas e instrumentais

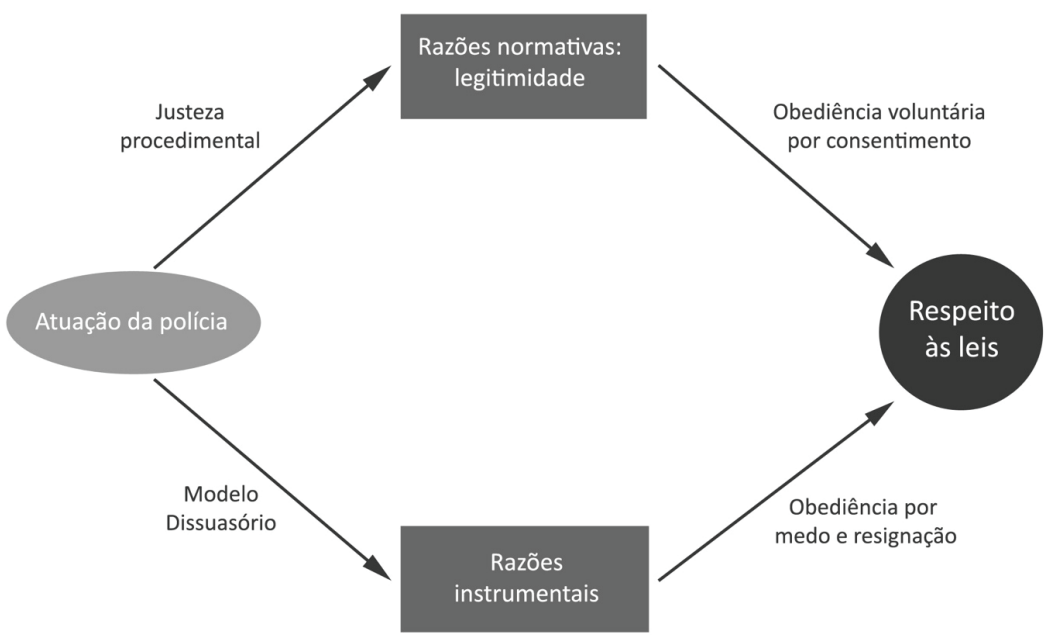

I. Justeza procedimental é o principal preditor da legitimidade policial. Ou seja, a confiança de que as autoridades agem com justeza procedimental teria maior impacto sobre a legitimidade do que a avaliação de eficácia.

II. A legitimidade tem impacto sobre o respeito às leis. Em outras palavras, quando as leis e autoridades são percebidas como legítimas, a população estaria mais propensa a respeitá-las.

\section{Estudos empíricos}

Pesquisas criminológicas a respeito dos preditores da obediência legal (e, em particular, sobre o papel das instituições de controle social), normalmente envolvem métodos de survey (Hinds e Murphy, 2007; Jackson et al., 2012a; Sunshine e Tyler, 2003; Tankebe, 2013; Wolfe et al., 2016). Os resultados podem, então, ser inferidos para um dado universo.

Sunshine e Tyler, por exemplo, amostraram 586 cidadãos da cidade de Nova Iorque em 2001. A partir de questões como "Os policiais tomam decisões a respeito de como lidar com problemas de modo 
justo?" e "Os policiais tratam as pessoas com justeza?", dentre outras, os pesquisadores puderam operacionalizar a variável latente percepção de justeza procedimental; ao perguntar aos respondentes se eles concordavam/discordavam de frases como "Você deve aceitar as decisões tomadas pela polícia, mesmo que acredite que eles estão errados" e "Você deve fazer o que os policiais dizem para você fazer mesmo quando você não entende as razões para as suas decisões", dentre outras, os pesquisadores puderam operacionalizar a variável latente dever de obedecer (Sunshine e Tyler, 2003).

Por meio de um modelo de equações estruturais, que incorpora todos os modelos de mensuração e uma análise de caminhos entre as variáveis latentes em um único modelo, os autores testaram tanto os antecedentes quanto as consequências da percepção de legitimidade policial na cidade de Nova Iorque. Justeza procedimental mostrou-se um melhor preditor de legitimidade do que a avaliação da performance policial, assim como legitimidade mostrou-se um melhor preditor tanto de cooperação com a polícia quanto de respeito às leis - e o efeito de legitimidade sobre o cumprimento da lei mostrou-se mais forte do que o efeito de percepção de risco. Em outras palavras, o estudo trouxe evidência para a hipótese subjacente a respeito da psicologia em que se baseia o modelo de policiamento baseado na justeza procedimental.

Uma estratégia similar foi adotada por Jackson et al. (2012a). Com dados de um survey nacional de amostra probabilística representativa de adultos da Inglaterra e do País de Gales, os autores buscaram testar o modelo de Tyler (1990) em uma população que não a estadunidense. Também assumindo uma abordagem reflexiva de mensuração (Jackson e Kuha, 2016), Jackson e colegas elaboraram questões que deveriam refletir dimensões de construtos latentes teoricamente assumidos. As medidas espelharam aquelas previamente utilizadas ou sugeridas por Tyler. Assim, para operacionalizar a concepção abstrata de "dever de obedecer", por exemplo, os entrevistados do survey responderam se concordavam ou discordavam, em escala ordinal, com três afirmações: "Você deve fazer o que a polícia diz para você fazer mesmo que você discorde", "Você deve aceitar as decisões tomadas pela polícia mesmo que ache que eles estão errados" e "Você deve fazer o que a polícia diz para você fazer mesmo que não goste do modo como eles tratam você". 
A estratégia analítica desses autores também envolveu modelagem de equações estruturais. Ao testar o caminho de confiança na justeza procedimental por parte da polícia até respeito às leis via legitimidade policial e dever de obedecer à autoridade, os autores evidenciaram que, assim como nos Estados Unidos, também no Reino Unido o dever de obedecer normativamente fundamentado e o alinhamento normativo com a polícia são melhores preditores da obediência legal do que a certeza de ser pego. Eles também demonstraram a importância de um policiamento que atue com procedimentos justos para aumentar a legitimidade da instituição policial (Jackson et al., 2012a). Em outras palavras, os autores trouxeram mais evidências para um modelo normativo de controle do crime em oposição ao modelo dissuasório.

\section{Mensurando a legitimidade policial}

A literatura recente a respeito dos preditores e dos impactos da legitimidade policial indica bastante discussão a respeito tanto da definição conceitual quanto das estratégias de operacionalização empírica da noção abstrata de legitimidade. Identificamos ao menos três abordagens distintas de mensuração desse fenômeno. Ainda que haja um paradigma conceitual próximo, essas três vertentes divergem consideravelmente em relação à operacionalização de legitimidade em seus desenhos de survey.

De maneira geral, o denominador comum das abordagens são os escritos weberianos (Weber, 2004) a respeito da dominação racional-legal. Em particular, a importância das discussões de Coicaud (2002) e de Beetham (1991) a respeito da legitimidade da autoridade é ressaltada pelos autores. Beetham, em especial, assume bastante importância na tradução das definições conceituais para a operacionalização empírica da noção de legitimidade, dado que ele define explicitamente: para que uma autoridade goze de legitimidade perante sua audiência, ela deve agir dentro dos preceitos normativos por ela estipulados; ela deve adquirir consentimento no que se refere aos seus comandos; e ela deve compartilhar com sua audiência uma série de valores.

O primeiro autor a trazer a discussão da legitimidade (policial) para o plano empírico, como dito acima, foi Tom Tyler (1990). O criminólogo americano introduziu uma abordagem de operacionalização que é seguida com frequência nos estudos desenvolvidos pela crimino- 
logia estadunidense (Sunshine e Tyler, 2003; Gau, 2014; Wolfe et al., 2016). “Uma propriedade psicológica de uma autoridade, instituição ou arranjo social que leva aqueles conectados a ela a acreditarem que ela é apropriada, adequada e justa" (Tyler, 1990:375), legitimidade é aqui compreendida como a combinação do dever de obedecer à polícia com a confiança depositada na instituição policial ${ }^{2}$. No diálogo com Beetham, a obrigação de obedecer aos comandos dos policiais estaria bastante próxima à ideia de consentimento, ao passo que a confiabilidade da polícia estaria relacionada aos valores compartilhados entre cidadãos e a instituição de segurança.

Um dos principais responsáveis por criticar a abordagem de Tyler, tanto em âmbito conceitual quanto em sua dimensão empírica, foi o criminólogo ganês Justice Tankebe (Bottoms e Tankebe, 2012; Tankebe, 2013). Em primeiro lugar, o autor sustenta que o núcleo do conceito de legitimidade está naquilo que cada sociedade acredita ser moralmente justificável no exercício do poder, isto é, seria impossível conceber uma noção abstrata de legitimidade que pudesse ser aplicada em contextos diversos. Nesse sentido, Tankebe critica a própria proposta generalista iniciada por Tyler. Assim, em concordância com a definição de Beetham, o criminólogo sustenta que a legitimidade policial pode ser resumida pela percepção pública de que a polícia atua dentro dos parâmetros legais e pelo compartilhamento de valores entre força policial e cidadãos. E esses valores seriam variáveis nas sociedades - cada grupo social teria expectativas normativas específicas em relação ao trabalho policial, sendo essas expectativas componentes principais da noção de legitimidade policial daquele contexto (Bottoms e Tankebe, 2012).

Em uma investigação empírica que aplica essas discussões, Tankebe (2013) argumenta que as expectativas normativas da população britânica em relação ao trabalho policial são: eficácia policial, isto é, as pessoas esperam que a força policial seja eficaz; justeza procedimental, isto é, as pessoas esperam um tratamento justo por parte dos policiais; e justeza distributiva, isto é, as pessoas esperam que a polícia aloque seus recursos de maneira justa. Esses três componentes resumiriam os valores compartilhados entre polícia e cidadãos (britânicos), bem como, combinados com a percepção de legalidade, consistiriam na legitimidade policial. Portanto, vê-se que a crítica de Tankebe não diz respeito exclusivamente à operacionalização empírica proposta por Tyler, mas à própria construção do problema: a percepção da atuação 
dos policiais dentro dos parâmetros da justeza procedimental não seria preditora da legitimidade policial, mas um componente.

Tankebe ainda elabora outra crítica importante em relação às pesquisas de Tyler. Para ele, a obrigação de obedecer à autoridade não é sequer um componente da legitimidade. Ao contrário, o autor argumenta que há diversas motivações para que um indivíduo obedeça às leis - moralidade individual, reconhecimento da autoridade, certeza de sanção, influência religiosa - sendo a legitimação apenas uma delas. Isto é, o dever de obedecer não compõe legitimidade porque legitimidade é preditora desse fenômeno. Em especial, Tankebe argumenta que a mera disposição à obediência não pode ser confundida com legitimidade justamente porque a motivação para essa disposição pode se dar por resignação ou mesmo por receio de coerção (Bottoms e Tankebe, 2012).

As críticas levantadas por Tankebe foram respondidas especialmente pelos criminólogos britânicos Jonathan Jackson e Ben Bradford, que dão continuidade à abordagem de Tyler no âmbito da teoria da justeza procedimental (Jackson et al., 2012a). De maneira geral, esses autores sustentam que a legitimidade se dá tanto pelo reconhecimento, por parte do público, da autoridade como legítima, quanto pela justificação normativa desse poder legal. O reconhecimento público se daria pela aquiescência e pela obediência voluntária consentida dos cidadãos, enquanto a justificação se daria por um alinhamento, em plano valorativo, das expectativas normativas entre cidadãos e autoridade (Jackson e Bradford, 2010).

Os criminólogos britânicos responderam algumas das críticas elaboradas por Tankebe, gerando um debate interessante em relação à natureza da noção de dever obedecer (Jackson et al., 2016). Em um texto recente, os autores reconhecem que a simples disposição à obediência pode se dar por resignação ou por coerção, o que envolveria um raciocínio instrumental distinto daquele proposto pela concepção de legitimidade, restrito a uma motivação baseada no consentimento. Assim, propõem uma nova operacionalização que dê conta dessas duas dimensões da obediência: a "obrigação coercitiva" e o "consentimento verdadeiramente livre". Seus resultados (em contexto britânico) indicaram que a percepção de justeza procedimental impacta positivamente o dever de obedecer consensualmente, que por sua vez impacta positivamente o comportamento de respeito às leis - 
resultados contrários foram encontrados no que se refere à obrigação coercitiva de obedecer. Esse estudo fortaleceu a perspectiva da teoria da justeza procedimental, ao mesmo tempo que trouxe a importância de se mensurar uma disposição à obediência baseada exclusivamente no consentimento verdadeiramente livre.

\section{Legitimidade em contexto}

Houve outros testes do modelo tyleriano de justeza procedimental baseados em métodos de survey. Trabalhos anteriores debruçaram-se sobre cenários dos Estados Unidos (Gau, 2014; Wolfe et al., 2016), do Reino Unido (Bradford, 2016; Tankebe, 2013) e da Austrália (Hinds e Murphy, 2007; Murphy, Hinds e Fleming, 2008). Ainda que a literatura a respeito da temática da legitimidade policial e da obediência às leis esteja emergindo em um crescente número de países - como Gana (Tankebe, 2009), África do Sul (Bradford et al., 2014) e Israel (Factor, Castilo e Rattner, 2014) -, pouca atenção foi dada a outros contextos fora do eixo anglo-saxão. Justice Tankebe (2009) aponta que existem poucos estudos similares conduzidos em novas democracias, o que coloca em discussão a possibilidade de generalização do modelo proposto por Tyler. Bottoms e Tankebe (2012) apontam que, embora possamos trabalhar com um conceito similar de legitimidade em diferentes sociedades, é preciso considerar que seu conteúdo, seus preditores e seus impactos podem variar, sugerindo que este é um conceito contextual.

Nesse sentido, Tankebe (2009) realizou uma pesquisa em que testa o modelo de Tyler em um contexto bastante diferente, Gana, ex-colônia britânica localizada na África Ocidental, que ao longo do último século alternou regimes democráticos e ditaduras até a redemocratização de 1993. Assim como no caso brasileiro (Batitucci, 2010), a polícia ganense foi criada com o objetivo de defender os interesses da metrópole e garantir a segurança de governantes e proprietários por meio do controle das camadas populares, alimentando um histórico de distanciamento e desconfiança na relação com a população, além da percepção de corrupção e da baixa eficiência no controle do crime. Assim como no Brasil, a redemocratização em Gana também foi marcada pelo aumento da criminalidade, medo e sensação de insegurança. 
Ao testar as hipóteses de Tyler no contexto de Gana, os resultados de Tankebe apontam que naquele país a legitimidade policial seria predita tanto pela percepção de justeza procedimental quanto na percepção de eficiência da polícia, quase que na mesma proporção. Isso ocorre porque, segundo o autor, a eficácia da polícia está ligada às necessidades básicas de proteção e segurança individual que são as justificativas mais primordiais para a existência do Estado e para o estabelecimento do contrato social hobbesiano, de maneira que a percepção de falta de eficácia pode ser um entrave para a detenção e exercício do poder legítimo (caso o Estado não ofereça o mínimo de proteção, sua própria existência poderia ser questionada). Esses resultados seriam diferentes daqueles encontrados em contextos anglo-saxões justamente porque naqueles países o medo e a sensação de insegurança não são tão severos e as pessoas se sentem mais protegidas, de maneira que a questão da eficácia ficaria em segundo plano. Além disso, esses resultados também podem estar relacionados com a forma como as instituições policiais foram concebidas e são percebidas pela população. Enquanto no caso inglês, por exemplo, a polícia tem uma tradição de minimizar o uso de recursos coercitivos, prevenir e mediar conflitos em uma estratégia de identificação e maior aproximação das camadas populares (Batitucci, 2010), no caso da polícia ganense a instituição ostenta um histórico de violência, distanciamento e repressão.

Isso não significaria dizer que a eficácia sozinha é o suficiente para a legitimidade, mas parece indicar que a eficácia é uma precondição necessária para a legitimidade. A pesquisa realizada em Gana indica ainda que a influência da eficácia sobre a legitimidade é mediada pela percepção de que a polícia age com justeza procedimental. Isso significa dizer que, mesmo que a polícia seja muito eficaz em manter a ordem e reduzir os crimes, as pessoas ainda não estarão propensas a legitimar a autoridade se as expectativas de tratamento justo não forem atendidas, ou seja, ambas as variáveis se mostraram igualmente importantes.

Em estudo desenvolvido a partir de um survey realizado em 2013 na cidade de São Paulo, Zanetic (2017) realizou uma investigação sobre os determinantes da confiança nas polícias e da legitimidade nas leis, testando algumas hipóteses presentes no cenário internacional. Em linhas gerais, o artigo buscou explorar a relação de uma série de variáveis relativas à justeza procedimental e à eficácia policial, en- 
contrando resultados específicos sobre os efeitos da relação entre a percepção de que policiais agem de maneira educada em suas abordagens (proxy de justeza procedimental) e a percepção de que a polícia mantém as ruas do bairro tranquilas (proxy de eficácia policial) como preditoras de confiança na polícia e legitimidade das leis.

Os resultados da pesquisa apontaram que tanto a variável proxy de justeza procedimental quanto a proxy de eficácia estão significativamente relacionadas com confiança na polícia, embora a relação seja menos forte no caso da segunda. Esses resultados se mostram similares aos achados das pesquisas acerca da justeza procedimental nos contextos britânico e norte-americano (Tyler e Jackson, 2013; Sunshine e Tyler, 2003; Tyler, 1990; e outros). A análise que explora o efeito da variável proxy de justeza procedimental sobre a legitimidade das leis também apresentou significância estatística (marginal, $\mathrm{p}<0.1$ ), embora com impacto significativamente menor do que com relação à confiança. Essa relação estatisticamente significativa entre justeza procedimental e legitimidade das leis também já foi encontrada em outros contextos, como demonstra trabalho realizado por Murphy, Tyler e Curtis (2009).

Uma diferença importante com essas pesquisas, entretanto, foi o fato de nesse estudo não ter sido encontrada nenhuma relação entre legitimidade das leis e eficácia policial. Nos estudos em que a relação entre a eficácia da polícia e a legitimidade foi estudada nos contextos britânico e norte-americano - nesses casos, entretanto, com relação à legitimidade policial - essa relação foi encontrada, ainda que em menor proporção do que quando comparada à justeza procedimental. Ao contrário do que vimos acerca da confiança, a análise estaria apontando, quando a variável dependente é a legitimidade das leis, uma relação ainda mais forte do que a preconizada pela teoria da legitimidade e da justeza procedimental, em que esta teria impacto maior sobre a legitimidade do que os fatores instrumentais, como a eficácia policial. Entretanto, uma vez que os estudos realizados no cenário internacional focalizaram de forma geral a legitimidade policial, e não a das leis, não é possível estabelecer uma relação direta entre os resultados encontrados com relação a esse aspecto.

Como observado em outros trabalhos voltados a analisar a relação entre legitimidade e ação policial, o estudo de Zanetic (2017) apontou a necessidade de se continuar avançando nas formas de mensuração da legitimidade e de se avançar nas perspectivas de captação de al- 
guns atributos importantes que se relacionam à propensão dos indivíduos em obedecer às leis, como a convicção (ou não) em fazê-lo, o medo das possíveis consequências de não obedecer, o cinismo legal. No trabalho aqui desenvolvido exploramos mais detalhadamente a questão da mensuração da legitimidade, com foco na legitimidade da polícia, verificando ainda quais os papéis de percepção de justeza procedimental e eficácia como seus preditores, além do efeito da legitimidade policial sobre o comportamento de respeito às leis.

\section{ESTE ESTUDO}

Para o desenvolvimento desta análise, utilizamos o survey conduzido por pesquisadores do Núcleo de Estudos da Violência da Universidade de São Paulo (NEV/USP), em 2015, em São Paulo. O questionário foi construído para investigar a imagem das instituições de segurança e justiça na capital paulista, a frequência dos contatos entre cidadãos e essas instituições e avaliação que os indivíduos fazem dessas interações. A amostra final conta com 1.806 cidadãos com 16 ou mais anos de idade.

O processo envolveu uma amostragem por aglomerados em dois níveis. Em um primeiro momento, foram sorteados setores censitários de forma proporcional ao tamanho (PPT) dos distritos administrativos do município. Em seguida, houve o sorteio dos domicílios em cada setor censitário selecionado - a seleção de entrevistados, a partir daí, se deu com a aplicação de cotas demográficas seguindo as descrições do último Censo para cada setor. Assim, houve cotas de sexo (54\% de mulheres), idade (média de 42 anos, com desvio-padrão de 17 anos), grau de instrução (97\% alfabetizados) e ocupação (64\% ocupados). Todas as entrevistas foram face a face no domicílio do entrevistado.

O questionário do survey foi composto por uma série de perguntas dispostas em alguns blocos específicos, como "confiança interpessoal", "medo e atitudes com relação à polícia", "obediência às leis", "vitimização", "confiança política e institucional", "polícia" e "justiça", além de uma seção destinada às perguntas relativas ao perfil sociodemográfico dos entrevistados. 


\section{Dados e medidas}

Neste estudo, compreendemos os julgamentos que os cidadãos fazem a respeito da legitimidade da polícia como o reconhecimento do poder das autoridades legais e a justificativa normativa desse poder legal - portanto, como uma composição de dimensões relativas a um senso de dever obedecer aos comandos policiais e alinhamento normativo com a polícia (Jackson e Bradford, 2010; Jackson et al., 2012a). Na análise empírica, a disposição de obediência foi mensurada através de duas formas distintas: na primeira forma, o dever de obedecer à polícia constituiu-se de uma variável binária mensurada através da questão "O(a) sr.(a) acha que deve obedecer à polícia mesmo quando acredita que ela está errada?"; a segunda forma constituiu-se de um indicador composto, utilizando-se da variável binária utilizada na primeira forma e de uma questão presente no survey indagando por que os entrevistados responderam "sim" ou "não" à questão sobre obedecer à polícia.

Essas respostas foram recategorizadas formando uma variável categórica de quatro níveis: i) aceite da autoridade; ii) protesto desobediente; iii) obrigação coercitiva; e iv) rejeição da autoridade. Além disso, o alinhamento normativo com a polícia foi mensurado a partir da questão "A polícia no seu bairro age de acordo com o que o(a) sr.(a) acha que é certo ou errado?", cujas respostas se distribuem numa escala ordinal de cinco pontos (sempre/ quase sempre/ às vezes / raramente/ nunca).

Confiança na justeza procedimental foi construída por meio de seis questões relativas à relação da polícia com o público. Entrevistados foram perguntados se a polícia em seu bairro: 1) Explica claramente por que revista ou prende as pessoas?; 2) Trata com respeito todas as pessoas: ricos e pobres, negros e brancos?; 3) Toma decisões que são justas e imparciais?; 4) Dá atenção as informações que as pessoas trazem?; 5) Assume e corrige seus próprios erros?; 6) Trata bem pessoas como você? Essas questões foram respondidas através de uma escala de cinco pontos (sempre/ quase sempre/ às vezes / raramente/ nunca). A estratégia analítica envolvida na mensuração desse construto envolveu análise fatorial confirmatória com indicadores categóricos ${ }^{3}$.

Da mesma maneira, a percepção de eficácia policial também foi mensurada a partir de uma abordagem reflexiva e integrou um modelo 
de mensuração de um fator. Os indicadores foram: Como o(a) sr.(a) avalia o trabalho da polícia no seu bairro em relação à diminuição do tráfico de drogas?; Como o(a) sr.(a) avalia o trabalho da polícia no seu bairro em relação à diminuição do assalto à mão armada?; Como o(a) sr.(a) avalia o trabalho da polícia no seu bairro em relação ao atendimento às chamadas de emergências (190)?; Como o(a) sr.(a) avalia o trabalho da polícia no seu bairro em relação ao atendimento na delegacia de polícia?; Como o(a) sr.(a) avalia o trabalho da polícia no seu bairro em relação à investigação de crimes?; Como o(a) sr.(a) avalia o trabalho da polícia no seu bairro em relação às manifestações / protestos?; Como o(a) sr.(a) avalia o trabalho da polícia no seu bairro em relação a manter as ruas do bairro tranquilas? Para essas questões, os entrevistados poderiam optar entre "muito bom", "bom", "ruim" e "muito ruim".

O comportamento de respeito às leis autorreportado também foi medido a partir de cinco questões específicas para as quais os entrevistados deveriam responder "sim" ou "não": 1) Alguma vez na vida o(a) sr.(a) tentou subornar um guarda de trânsito ou rodoviário para evitar multa?; 2) Comprou produtos falsificados ou piratas?; 3) Usou sinal de TV a cabo sem pagar por isso?; 4) Comprou produtos sem nota fiscal para reduzir o preço?; 5) Pagou o médico ou dentista particular sem recibo? Binárias, as respostas das cinco questões foram operacionalizadas com 1 ("sim") e 0 ("não") e, em seguida, somadas, formando um índice aditivo de 0 (o indivíduo que alegou não ter cometido nenhuma dessas ilegalidades) a 5 (o indivíduo que alegou ter cometido todas elas) em distribuição de contagem.

\section{Estratégia analítica}

A estratégia analítica deste estudo envolveu três etapas. Em primeiro lugar, buscamos investigar a associação entre percepções de justeza procedimental e de eficácia policial e tanto o alinhamento normativo com a polícia como o indicador binário de dever de obedecer à polícia, aqui compreendidos como componentes da legitimidade policial, bem como sua associação com o comportamento de respeito às leis. A partir de uma abordagem reflexiva de mensuração, consideramos que os indicadores mensurados não formam conceitos - os quais não são observáveis -, mas têm sua associação gerada por uma variável latente (Oliveira et al., 2019) ${ }^{4}$. Assim, utilizamos modelos de equações estruturais generalizados para investigar as relações entre 
as variáveis latentes. Os modelos de mensuração de percepção de justeza procedimental e de eficácia policial foram gerados considerando a distribuição ordinal dos indicadores observáveis. $\mathrm{O}$ indicador de dever de obedecer à polícia é binário, assim foram realizados modelos de regressão logística binomial nessa direção. $\mathrm{O}$ indicador de alinhamento normativo com a polícia é ordinal, assim foram realizados modelos de regressão logística ordinal nessa direção. Por fim, o respeito às leis foi mensurado a partir da soma de cinco itens binários, assim seguindo uma distribuição de contagem - portanto, foram realizados modelos de regressão de Poisson nessa direção.

Todos os modelos de regressão incluem, como variáveis de controle: raça (autodeclarada: branca / não branca); idade (contínua); classe social (distribuição ordinal a partir do critério Brasil); e sexo (masculino ou feminino). Isso não significa que nós estamos investigando se o modelo varia conforme essas clivagens sociais (não foram incluídas interações, por exemplo), mas que estamos controlando pelas possibilidades de associações entre as variáveis de interesse se darem a partir desses grupos.

O objetivo dessa primeira etapa da investigação foi investigar os preditores da legitimidade policial (na expectativa de que o efeito da percepção de justeza procedimental fosse não só positivo e significativo, como substantivamente maior do que o efeito de percepção de eficácia policial), bem como os seus impactos (na expectativa de que tanto o dever de obedecer à polícia quanto o alinhamento normativo fossem negativos e estatisticamente significativos na predição de comportamentos ilegais).

Em seguida, foi realizada a análise de conteúdo das respostas espontâneas concernentes ao motivo de dever (ou não) obedecer à polícia. Para que essas respostas pudessem ser incorporadas em um modelo estatístico e com o objetivo de controlar por possíveis vieses dos pesquisadores, nós desenvolvemos um processamento de dados que envolveu categorização, classificação e validação das respostas abertas. O processamento dos dados qualitativos seguiu os seguintes passos.

Em primeiro lugar, foi realizada uma análise das variáveis abertas de forma a se chegar a uma medida capaz de captar a legitimidade no contexto paulistano. Foram testadas algumas variáveis e realizadas análises de confiabilidade destas, por meio de cruzamentos 
com outras variáveis constituídas através do survey, como questões ligadas a direitos humanos (violência e corrupção policial), respeito/ cumprimento das leis, confiança na polícia, alinhamento moral com a polícia.

O critério para o qual foi verificada a confiabilidade da variável foi o alinhamento de suas categorias com os itens das demais variáveis com as quais a variável foi analisada, de acordo com os pressupostos que guiam este estudo. Esses pressupostos relacionam-se sobretudo à perspectiva de existência, como estamos discutindo neste artigo, de uma obediência orientada pelo medo e resignação frente às autoridades e também por uma não obediência orientada pela consciência dos direitos e da ilegalidade das ações realizadas pelas autoridades.

Essa análise de diferentes formas de organização das respostas abertas em uma variável fechada resultou em uma variável formada por quatro categorias, discutidas ao longo do artigo, nomeadas como: aceite da autoridade; protesto desobediente; obrigação coercitiva; e rejeição da autoridade. Essas categorias, via de regra, relacionavam-se com as demais variáveis de forma hierárquica, por exemplo com a categoria "aceite da autoridade" correspondendo a um índice mais elevado de respostas "confia muito" nas polícias, e declinando sucessivamente, com o menor índice correspondendo à categoria "rejeição da autoridade"; ou com um maior índice de pessoas que consideram que a "polícia no seu bairro age de acordo com o que o(a) sr.(a) acha que é certo ou errado", e a "rejeição da autoridade" correspondendo ao menor índice.

Em seguida, foi realizado um processo de validação da variável, incluindo as seguintes etapas: 1) Leitura e pré-codificação das respostas considerando as ideias mais recorrentes (passo conduzido por dois pesquisadores trabalhando individualmente); 2) Discussão das pré-categorias criadas e ajustes feito para chegar a uma proposta consensual; 3) Apresentação e discussão da proposta de categorização com outros pesquisadores familiarizados com o tópico de investigação, mas que não participaram de qualquer etapa anterior; 4) Classificação de todas as respostas de acordo com as categorias propostas; 5) Recategorização feita por três pesquisadores voluntários (que não estiveram envolvidos nas etapas anteriores), aplicando a categorização proposta ao banco inteiro, o que resultou em uma taxa de concordância de $85 \%$; 6) Discussões em torno das discrepâncias e conseguinte 
correção de cerca de 5\% das classificações originais; e 7) Passo final que envolveu o colapso de algumas categorias, orientado pelas quatro categorias já anteriormente constituídas. Nesta etapa foram feitos ajustes para a constituição da variável final, sendo nomeadas as quatro categorias conforme descrito acima.

Por fim, voltamos a testar as hipóteses relativas aos preditores e aos impactos da legitimidade policial em São Paulo, agora incorporando as categorias criadas por meio da análise de conteúdo das respostas abertas. Assim, o dever de obedecer à polícia foi compreendido como uma variável ordinal em ordem crescente de legitimidade desde a rejeição até o aceite da autoridade, passando respectivamente pela obrigação coercitiva e pelo protesto desobediente. A estratégia analítica para o teste dessas hipóteses seguiu a mesma lógica da primeira etapa: utilizamos um modelo de equações estruturais generalizado para investigar as relações não lineares entre as variáveis latentes. Assim, utilizamos modelos de regressão logística ordinal para testar os efeitos de justeza procedimental e eficácia tanto sobre alinhamento normativo (como na primeira etapa) quanto sobre dever de obedecer à polícia; e um modelo de regressão de Poisson para testar o efeito de dever de obedecer à polícia e de alinhamento normativo sobre a obediência às leis autoinformada. Novamente, todos os modelos de regressão foram controlados por raça, sexo, idade e classe social. A expectativa para esta análise era obter um resultado mais robusto concernente aos preditores e aos impactos da legitimidade policial em São Paulo.

\section{RESULTADOS}

Etapa 1: modelo com indicador binário de dever de obedecer à polícia

O teste do modelo teórico apresentado na Figura 1 acima foi realizado por meio de um modelo generalizado de equações estruturais. A variável dependente final, somatória de atitudes ilegais admitidamente cometidas pelos entrevistados, foi estimada por meio de uma regressão de Poisson a partir dos dois componentes da legitimidade policial - alinhamento normativo e dever de obedecer. Nessa primeira etapa, foi utilizado um indicador binário de dever de obedecer à polícia. Os efeitos das percepções de justeza procedimental e de eficácia policial sobre a legitimidade também foram testados. A Figura 2 a seguir apresenta os resultados encontrados. 
Figura 2

Modelo de equações estruturais - indicador binário de dever de obedecer

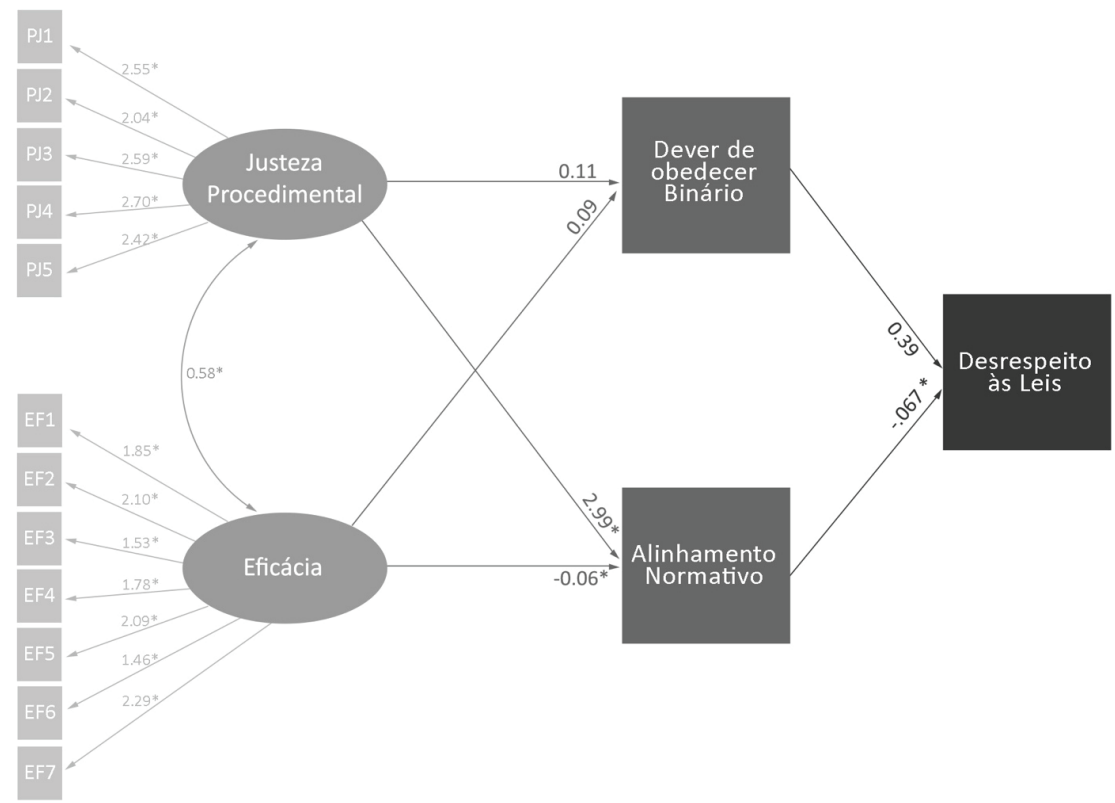

Obs.: Modelo generalizado de equações estruturais (Mplus 7.11).

Indicadores ordinais de justeza procedimental e eficácia.

Regressão logística ordinal prevendo alinhamento normativo, regressão logística binomial prevendo dever de obedecer à polícia, regressão de Poisson prevendo admissão de cometimento de atitudes ilegais.

Todos os modelos de regressão foram controlados por raça, idade e classe social.

Modelos de mensuração e parâmetros padronizados estimados reproduzidos.

$*$ : $p<0.05$.

A percepção de justeza procedimental é preditora significativa da legitimidade policial? De acordo com a Figura 2, não. Ainda que a associação entre confiança na eficácia policial e os dois componentes da legitimidade não sejam diferentes de zero na população, conforme previmos, a expectativa da população paulistana relativa ao tratamento oferecido pelos policiais não está associada com o dever de obedecer à polícia. Por outro lado, a confiança na justeza procedimental tem um coeficiente positivo sobre o alinhamento normativo com a polícia, isto é, os cidadãos que confiam no tratamento a ser recebido pelos policiais são aqueles cujas expectativas normativas estão alinhadas aos valores morais da instituição policial. Ainda assim, como apenas um dos dois componentes da legitimidade se comporta conforme esperávamos, não é possível afirmar que há embasamento empírico para aceitar a hipótese tyleriana no contexto paulistano até esse momento. 
O mesmo pode ser dito em relação à predição de comportamentos ilegais. Ainda que o alinhamento normativo com a polícia esteja negativamente associado com a admissão de cometimento de pequenas ilegalidades, o dever de obedecer à polícia mesmo quando se considera que ela está errada não está associado a mudanças no comportamento do cidadão concernente à lei nessas situações. Sendo o dever de obedecer a um importante componente da legitimidade policial, também aqui não é possível afirmar que há embasamento empírico para aceitar a hipótese tyleriana no contexto paulistano.

No intuito de investigar se essa é uma particularidade da sociedade paulistana ou se há alguma informação a mais na própria mensuração do dever de obedecer à polícia, procedemos à análise de conteúdo referente às motivações da obediência (ou não) à autoridade.

\section{Etapa 2: criação das categorias de dever de obedecer à polícia}

Conforme discutido acima, a questão "O(a) sr.(a) acha que deve obedecer à polícia mesmo quando acredita que ela está errada?" busca mensurar um sentimento de dever de obediência à autoridade acima da própria moralidade individual. Baseada em estudos anteriores realizados por Tyler (Tyler, 1990; Sunshine e Tyler, 2003) e outros pesquisadores (Jackson et al., 2012a; 2016), essa questão é nuclear na mensuração da legitimidade policial no sentido de que o dever de obediência por consentimento seria um dos principais preditores do comportamento de respeito às leis. Nesse sentido, dois terços da população paulistana estaria no grupo dos que legitimam a autoridade policial, ao passo que apenas um terço estaria rejeitando essa autoridade.

Quando se considera o contexto brasileiro, e paulistano em particular, no entanto, essa pergunta pode adquirir uma significação distinta da observada em outros locais. A motivação para obedecer a um policial quando ele está errado pode ter mais frequentemente uma conotação de uso excessivo da força e de cometimento de ilegalidades, por exemplo, o que significa que uma resposta positiva a essa questão não indica necessariamente um dever de obediência por consentimento. Ao contrário, pode indicar uma obediência por medo de coerção, o que é essencialmente oposto à noção de legitimidade. 
Nesse sentido, procedemos à análise das respostas espontâneas à questão seguinte: "Por que o(a) sr.(a) acha que (não) deve obedecer à polícia mesmo quando acredita que ela está errada?". Dentre os dois terços da amostra que responderam sim à primeira questão, apenas $40 \%$ relataram motivos que indicassem uma noção de "consentimento verdadeiramente livre" (Jackson et al., 2016). Os outros 60\% (isto é, a maioria dos que responderam sim à questão sobre dever de obedecer à polícia) deram respostas que indicavam uma forma coercitiva de obrigação, o que inclui medo de retaliação ou de punição.

E assim como uma resposta positiva à pergunta sobre dever de obedecer não reflete uma atitude legitimadora em relação à autoridade, vimos que uma resposta negativa também não reflete, necessariamente, uma rejeição à polícia. Dentre o terço da população amostrada que respondeu não à primeira questão, de fato a maioria deles (62\%) indicou algum tipo de dever moral de desobedecer e deslegitimação; ainda assim, os outros 38\% relataram motivos relacionados a algum tipo de protesto desobediente que aceita a autoridade, mas que não deve obedecer àquele indivíduo-policial em particular, como se o comando dado, pelo contexto ou pelas características específicas, em si fosse ilegítimo.

Foram criadas quatro categorias, relacionadas abaixo em ordem decrescente de legitimidade conferida à autoridade policial:

- Aceite da autoridade: essa categoria combina os entrevistados que indicaram um dever moral de obedecer à polícia. Trata-se do grupo que mais se aproxima à noção de legitimidade no sentido de um "consentimento verdadeiramente livre". As respostas desses entrevistados estão relacionadas ao dever de obedecer à autoridade, ao dever dos cidadãos de respeitar os policiais enquanto profissionais ${ }^{5}$;

- Protesto desobediente: Entrevistados que estariam inclinados a desobedecer aos comandos policiais em situações nas quais considerassem que os policiais estivessem agindo de maneira inapropriada, mas que mantivessem a possibilidade de apelar para outras instituições mediadoras para resolver esse conflito. Nesse contexto, desobediência não significa deslegitimar a instituição policial, mas questionar as ações individuais dos agentes policiais quando há um desentendimento. No geral, essas respostas 
mencionam o direito à resistência e a não agir em desacordo com os próprios valores individuais, além de levantarem a possibilidade de estabelecer diálogos e proteger seus direitos ${ }^{6}$;

- Obrigação coercitiva: Obediência motivada por medo de sofrer consequências, legais ou ilegais, caso engajem em desobediência. Respostas dessa categoria indicam que os entrevistados acreditam que devem obedecer à polícia por medo de retaliação, sanção ou violência física. Essa categoria também inclui as respostas originalmente classificadas como "Resignação" porque elas indicam a falta de alternativas e impotência perante a força policial";

- Rejeição da autoridade: Entrevistados que justificam desobedecer à polícia devido a uma imagem negativa da instituição, indicando um dever moral de desobedecer. Percepções de má conduta policial como corrupção, abuso e violência, assim como baixa confiança nos policiais, levariam os entrevistados à liberdade de não obedecer à políciå .

Etapa 3: modelo com indicador ordinal de dever de obedecer à polícia

$\mathrm{Na}$ terceira etapa deste estudo, repetimos o teste da teoria da justeza procedimental em São Paulo utilizando um modelo de equações estruturais generalizado. O modelo testado foi o mesmo cujos resultados foram apresentados na Figura 2, mas substituindo o indicador binário de dever de obedecer à polícia pelo indicador ordinal cujas categorias foram criadas pela análise de conteúdo apresentada acima. Assim, em ordem crescente, o indicador ordinal de obrigação de obedecer à polícia é composto pelas categorias: rejeição da autoridade, obrigação coercitiva, protesto desobediente e aceite da autoridade. Nessa direção, foram agora realizados modelos de regressão logística ordinal. Os resultados podem ser conferidos a seguir na Figura 3. 
Figura 3

Modelo de equações estruturais - indicador ordinal de dever de obedecer

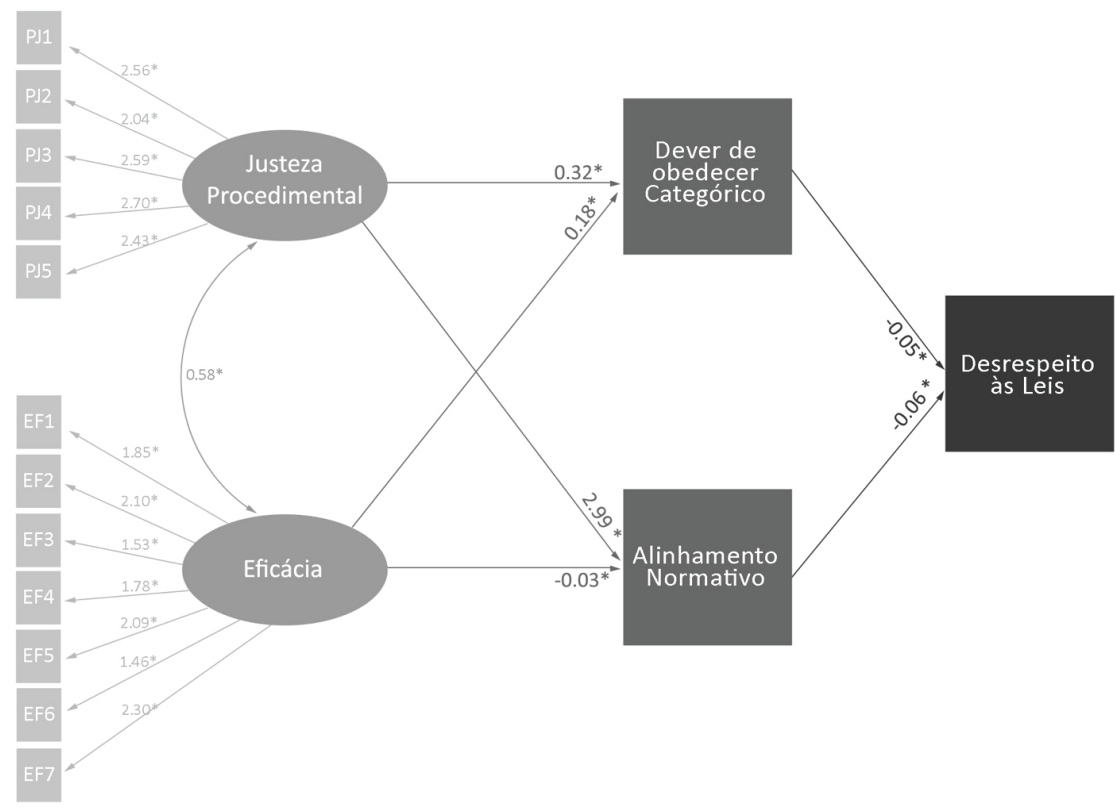

Obs.: Modelo generalizado de equações estruturais (Mplus 7.11).

Indicadores ordinais de justeza procedimental e eficácia.

Regressão logística ordinal prevendo alinhamento normativo, regressão logística ordinal prevendo dever de obedecer à polícia, regressão de Poisson prevendo admissão de cometimento de atitudes ilegais. Todos os modelos de regressão foram controlados por raça, idade e classe social.

Modelos de mensuração e parâmetros padronizados estimados reproduzidos.

$*$ p $<0.05$.

Assim como no modelo anterior, o caminho da percepção de justeza procedimental à obediência via alinhamento normativo com a polícia não só é estatisticamente significante como substantivamente relevante, em especial quando comparado com a percepção de eficácia policial. Esse aspecto da hipótese testada se manteve. Mas diferentemente do modelo apresentado na Figura 2, agora o caminho via dever de obedecer à polícia também é significante. Se com o indicador binário não foi possível estimar o papel mediador da legitimidade policial entre a percepção de justeza procedimental e a admissão de cometimento de atitudes ilegais, conforme previra a teoria testada, a Figura 3 demonstra que utilizando as categorias criadas na análise de conteúdo a hipótese testada pode ser aceita. 
Há uma associação positiva entre a confiança na justeza procedimental e a escala ordinal de dever de obedecer à polícia, o que significa que com aumentos na expectativa positiva do tratamento a ser recebido pelos policiais se espera um aumento na probabilidade do cidadão aceitar a autoridade policial. Ao mesmo tempo, quanto mais o cidadão apresenta um dever moral de obedecer à polícia, menos atitudes ilegais ele admite cometer. Isso significa que, desde que mensurada apropriadamente, a relação entre legitimidade policial e a obediência às leis em São Paulo segue o comportamento previsto pela teoria.

\section{DISCUSSÃO}

Há evidências para sustentar a hipótese da justeza procedimental no cenário paulistano? De acordo com esta pesquisa, sim. Conforme indicam os resultados da Figura 3, os cidadãos que têm expectativa de interações e decisões de alta qualidade por parte dos policiais, com imparcialidade, neutralidade e direito à voz, são aqueles cidadãos que acabam por conferir altos níveis de legitimidade à instituição policial, percebendo as mesmas noções de certo e errado que a polícia e estando dispostos a consentir com os comandos da autoridade mesmo quando há discordância. Tal qual esperado, os efeitos da expectativa de justeza procedimental tanto sobre o dever de obedecer quanto sobre o alinhamento normativo são mais fortes do que os efeitos da percepção de eficácia, o qual, além de não ser estatisticamente significativo em alguns casos, é consideravelmente fraco. Isso significa, conforme previra a hipótese tyleriana, que a conferência de legitimidade à autoridade por parte dos cidadãos está mais relacionada aos meios do que aos fins - ao modo como os indivíduos esperam ser tratados do que a possíveis resultados positivos no controle da criminalidade.

Além disso, a Figura 3 ainda indica que quanto mais os cidadãos se aproximam da ideia de um dever de obedecer à polícia por consentimento verdadeiramente livre, em oposição à rejeição moral da autoridade, menor a probabilidade de eles reportarem o cometimento de alguma das cinco atitudes ilegais que investigamos. Isto é, tal qual havíamos previsto a partir do desenvolvimento das pesquisas internacionais (Sunshine e Tyler, 2003; Jackson et al., 2012a), a internalização das normas e o dever moral de obediência estão positivamente associados ao comportamento de respeito às leis - ou, ao menos, à 
declaração de um comportamento de respeito às leis. Nesse sentido, este teste da hipótese da justeza procedimental em contexto latino-americano chegou a resultados interessantes: também aqui a forma de atuação da polícia influencia diretamente o comportamento dos indivíduos em relação às leis.

No entanto, o teste dessa hipótese no contexto da cidade de São Paulo trouxe questões novas que são de interesse à literatura. Dois pontos merecem discussão, ambos associados ao papel coercitivo da polícia: a influência do enquadramento social e das relações de autoridade; e a mensuração da variável latente "legitimidade policial".

O cenário paulistano difere do contexto em que a hipótese da justeza procedimental é tradicionalmente testada. Conforme discutido acima, trata-se de uma conjuntura em que há uma acentuada desigualdade socioeconômica e uma polícia (militarizada) bastante violenta, especialmente quando se consideram as clivagens de classe e raça'. As políticas de segurança pública, de maneira geral, tendem a enfatizar o modelo preconizado pela teoria da dissuasão (Zanetic et al., 2016).

É nesse contexto que a maior parte da população paulistana se situa justamente na categoria de "obrigação coercitiva" de obediência, isto é, os cidadãos de São Paulo acreditam que devem obedecer à polícia porque não há outra alternativa, porque temem as consequências de uma desobediência, porque não querem ser punidos. Nesse cenário, a crítica elaborada por Bottoms e Tankebe (2012) se mostra pertinente: a mera disposição a obedecer a uma autoridade mesmo quando se discorda dela, em si, não indica legitimidade.

Outro aspecto importante ressaltado pelos resultados aqui apresentados diz respeito à mensuração da noção abstrata de "legitimidade policial", em particular da ideia de uma disposição à obediência normativamente fundamentada. Ainda que relacionada à discussão desenvolvida acima, esse ponto é mais amplo, já que pode ir além das especificidades do contexto paulistano.

No caso da cidade de São Paulo, fica evidente a dissociação entre as perguntas que buscam saber se o entrevistado estaria disposto a obedecer à polícia mesmo quando acredita que a polícia está errada e a percepção de legitimidade policial. Isso porque tanto aqueles que 
respondem sim, mas motivados por coerção ou resignação, quanto aqueles que respondem não, mas legitimam a autoridade e se engajam em um protesto legítimo, são categorias factíveis. Mas isso não pode ocorrer em outros contextos?

A análise de conteúdo das respostas espontâneas concernentes à motivação do dever de obedecer à polícia se mostrou essencial no teste da hipótese da justeza procedimental. É de impacto considerável o fato de a Figura 2 - que utilizou o indicador binário ("sim, devo obedecer" / "não, não devo obedecer") - não ter apresentado resultados significativos e mesmo ter contradito as expectativas teóricas das nossas hipóteses, enquanto os resultados da Figura 3 - cujos modelos são rigorosamente os mesmos, apenas trocando o indicador binário pelo indicador ordinal de obediência (rejeição da autoridade, obediência coercitiva, protesto desobediente, dever moral de obedecer) - se mostraram substantivamente interessantes. As medidas de dever de obedecer, nas pesquisas internacionais de uma maneira geral, estão enviesadas pelas motivações dessa obediência, de modo que apenas respostas abertas poderiam solucionar o problema, ou esses resultados dizem respeito a uma especificidade do contexto paulistano?

Até o momento, não há respostas para essa pergunta. O que podemos sustentar é que, ao menos no caso da cidade de São Paulo, as medidas tradicionais de legitimidade policial revelaram neste estudo importantes limitações, sugerindo a necessidade de mediação por respostas espontâneas. Com isso, as categorias de protesto desobediente e obrigação coercitiva, centrais para os nossos resultados, mostram-se relevantes para a análise do tema. É possível que em outros contextos a análise de conteúdo a respeito das motivações da disposição em obedecer à polícia também altere os resultados do teste da hipótese da justeza procedimental.

\section{Limitações}

Evidentemente, o estudo que apresentamos aqui tem uma série de limitações que merecem ser pontuadas. É sensato, por exemplo, questionar a própria possibilidade de se mensurar, com surveys quantitativos, questões abstratas como o nível de legitimidade policial de uma dada população. Foi possível mensurar de fato as variáveis latentes que representam as percepções de justeza procedimental e eficácia 
policial? As medidas de comportamento ilegal autorreportado podem ser consideradas indicadores válidos e confiáveis?

Por certo, a realidade social é mais complexa do que a figura dada por um desenho de survey (mesmo representativo). Nesse sentido, nenhum estudo dessa natureza será integralmente conclusivo em relação a esse tópico. Ainda assim, a abordagem reflexiva de mensuração que propomos aqui avança consideravelmente em direção a uma melhor compreensão da realidade social - isso porque a própria mensuração das variáveis latentes se torna um teste de uma hipótese teórica e previamente definida e confrontada com a força da associação entre os indicadores (Oliveira et al., 2019).

Outra limitação de um desenho de survey como o que apresentamos aqui diz respeito aos objetivos da análise. Ainda que as associações entre variáveis latentes sejam realizadas, não é possível dar um passo maior - que seria de interesse científico - e afirmar que se trata de relações causais. Sendo um estudo observacional, essa é uma limitação intrínseca ao desenho de pesquisa. No entanto, este artigo ganha força quando se considera o teste de uma hipótese definida previamente e retirada da literatura, uma hipótese bastante testada em diversos contextos sociais e mesmo em desenhos experimentais (MacQueen e Bradford, 2015). Ainda que sejam apenas correlações, elas são fortemente amparadas pela discussão teórica desenvolvida pela literatura criminológica. Nesse sentido, a validade da presente investigação pode ser confirmada.

\section{CONSIDERAÇÕES FINAIS}

O presente artigo testou um modelo baseado na teoria da justeza procedimental e da legitimidade policial no contexto brasileiro. Utilizando dados de um survey representativo dos moradores adultos da cidade de São Paulo entre junho e julho de 2015, coletado por pesquisa desenvolvida no Núcleo de Estudos da Violência da Universidade de São Paulo, utilizamos medidas semelhantes a estudos que testaram a hipótese sugerida por Tyler (1990) em diversos contextos, como Estados Unidos (Sunshine e Tyler, 2003; Gau, 2014; Wolfe et al., 2016), Reino Unido (Jackson et. al., 2012; Tankebe, 2013; Bradford, 2016) e Austrália (Hinds e Murphy, 2007; Murphy, Hinds e Fleming, 2008). 
O tema da legitimidade policial ainda está sendo introduzido no Brasil (Zanetic et al., 2016; Zanetic, 2017; Oliveira et al., 2019), de modo que uma primeira investigação empírica sobre esse assunto se faz importante. Qual o papel, afinal, das instituições de segurança e justiça, e particularmente da polícia, na influência de comportamentos dos cidadãos no que se refere ao respeito às leis? Quais as estratégias mais eficazes a serem adotadas por políticas de segurança pública para garantir a deferência às normas sociais?

De um modo geral, as políticas de segurança pública adotadas no Brasil se orientam pelo modelo dissuasório (Zanetic et al., 2016). Isto é, são estratégias que focam o maior policiamento ostensivo, maior vigilância, mais policiais (e mais armados) na rua, avaliação da eficácia a partir de indicadores de coerção - ou seja, são estratégias que se utilizam de incentivos negativos no intuito de convencer o indivíduo interessado em se engajar em comportamento criminoso de que essa atitude não vale os riscos. A certeza da punição faria com que as pessoas respeitassem as leis.

Independentemente do sucesso que essa abordagem pode obter, o comportamento de respeito às leis atingido seria negativo, baseado no medo e na resignação. Não envolveria a internalização das normas sociais. Não seria um respeito voluntário e positivo, baseado em um dever de obedecer normativamente fundamentado.

Os resultados deste artigo, em consonância com os estudos feitos em outras partes do mundo, indicam a potencialidade de políticas de segurança pública que fortaleçam as estratégias voltadas à ampliação da legitimidade policial, em detrimento da focalização em estratégias centradas apenas em práticas dissuasórias. Com o objetivo de assegurar uma obediência voluntária às leis, orientada por um consentimento verdadeiramente livre em relação aos comandos da autoridade policial, é fundamental que a atuação dos policiais seja mais concentrada na justeza procedimental.

Quando os agentes da autoridade agem de maneira justa, imparcial, dando voz e reconhecendo a perspectiva do cidadão, os indivíduos tendem a conferir maior legitimidade à instituição policial, conforme demonstramos empiricamente. E quanto maior a percepção de legitimidade policial, menor a probabilidade de os cidadãos reportarem 
o cometimento de atitudes ilegais. Trata-se de um outro modelo de segurança pública.

Evidentemente, ainda são necessários estudos para que de fato se verifique o efeito das interações entre cidadãos e policiais sobre o respeito às leis por mediação da conferência de legitimidade. Um desenho experimental envolvendo o treinamento de um grupo de policiais a partir do prisma da justeza procedimental, por exemplo, seria fundamental para investigar as relações causais dos encontros entre cidadãos e policiais. Ainda assim, este artigo trouxe evidências do impacto que um tratamento justo da autoridade tem sobre o comportamento dos indivíduos, enfatizando a importância de uma segurança pública que se projete para além da dissuasão, em direção a um policiamento por consentimento.

(Recebido para publicação em 6 de agosto de 2017)

(Reapresentado em 11 de julho de 2019)

(Aprovado para publicação em 24 de agosto de 2019)

\section{NOTAS}

1. Respeitar as leis é aqui compreendido no âmbito comportamental, isto é, trata-se da ação individual de não infringir as leis, e não no âmbito dos valores. O termo usado na literatura internacional é compliance with the law - ainda que não seja ideal, optamos por traduzir pela expressão "respeito às leis" para não confundir com o valor dever obedecer (duty to obey), mas é importante enfatizar que estamos nos referindo ao nível dos comportamentos.

2. No original, duty to obey e trustworthiness.

3. O modelo de mensuração integra o modelo de equações estruturais, cujos resultados são mostrados a seguir.

4. A dificuldade de mensurar fenômenos não observáveis é um problema comum nas pesquisas das Ciências Sociais, em especial naquelas que se valem de desenhos de survey. Como, por exemplo, elaborar um questionário fechado que dê conta da mensuração do reconhecimento, por parte de um cidadão, da polícia como autoridade legítima? Uma possibilidade para essas situações é a abordagem reflexiva de mensuração, que explicita tais fenômenos como não observáveis, mas busca mensurar seus efeitos sobre indicadores empíricos. Para uma discussão mais detalhada a respeito da abordagem reflexiva de mensuração e da modelagem de variáveis latentes em desenhos de survey, cf. Oliveira et al., 2019.

5. Exemplos de respostas classificadas nessa categoria são: "É dever do cidadão agir de acordo com a lei", "Nós devemos obedecer as autoridades", "A polícia representa a lei e deve ser respeitada", "Não importa se ela está certa ou errada, nós devemos obedecer à polícia", "Eles estão fazendo o seu trabalho", "Obedecer é melhor para todos". 
6. Exemplos de respostas classificadas nessa categoria são: "Eles estão errados e se eu obedecer eu vou contra as minhas crenças", "Porque eu tenho direitos como cidadão", "As leis foram feitas para todos e eu posso recorrer", "Eu tenho que fazer o policial entender o meu ponto de vista".

7. Exemplos de respostas classificadas nessa categoria são: "Para que eu não sofra as consequências", "Para evitar punição", "Porque senão a gente apanha", "Porque você tem que obedecer, não tem jeito", "Porque eles sempre estão certos".

8. Exemplos de respostas classificadas nessa categoria são: "Porque eu não gosto dos policiais", "Porque eles matam pessoas inocentes", "Porque eles são corruptos e piores do que muito bandido", "Porque a gente não pode confiar neles".

9. As clivagens de marcadores sociais da diferença nas percepções públicas a respeito da polícia e da autoridade são um tema importante no contexto brasileiro. Nesse sentido, é necessário enfatizar a importância de se problematizar as dimensões específicas de classe e raça em futuros trabalhos nessa temática. Além disso, a distribuição socioespacial dos cidadãos em uma metrópole como São Paulo também deve ser levada em consideração. 


\section{REFERÊNCIAS BIBLIOGRÁFICAS}

BATITUCCI, Eduardo. (2010), “A evolução institucional da Polícia no século XIX: Inglaterra, Estados Unidos e Brasil em perspectiva comparada". Revista Brasileira de Segurança Pública, v. 4, n. 7, pp. 30-47.

BEETHAM, David. (1991), The legitimation of power. London: Macmillan.

BOTTOMS, Anthony e TANKEBE, Justice. (2012), “Beyond procedural justice: a dialogic approach to legitimacy in criminal justice". The Journal of Criminal Law and Criminology, v. 102, n. 1 , pp. $119-70$.

BRADFORD, Ben. (2016), "Policing and social identity: procedural justice, inclusion and cooperation between police and public". Policing and Society, v. 24, n. 1, pp. 22-43.

BRADFORD, Ben et al. (2014), "What price fairness when security is at stake? Police legitimacy in South Africa". Regulation and Governance, v. 8, n. 2, pp. 246-268.

COICAUD, Jean-Marc. (2002), Legitimacy and politics: a contribution to the study of political right and political responsibility. Cambridge: Cambridge University Press.

DURKHEIM, Émile. (1999), As regras do método sociológico. São Paulo: Martins Fontes.

ELIAS, Norbert. (1997), O processo civilizador. Volume 1: Uma história dos costumes. Rio de Janeiro: Jorge Zahar.

FACTOR, Roni; CASTILO, Juan Carlos; RATTNER, Arye. (2014), “Procedural justice, minorities and religiosity". Police Practice and Research, v. 15, n. 2, pp. 130-142.

FAGAN, Jeffrey; MEARES, Tracey. (2008), "Punishment, deterrence and social control: the paradox of punishment in minority communities". Ohio State Journal of Criminal Law, v. 6, pp. 173-229.

FREUD, Sigmund. (2011), O mal-estar na civilização. São Paulo: Penguin Classics/ Companhia das Letras.

GAU, Jacinta. (2014), "Procedural justice and police legitimacy: a test of measurement and structure". American Journal of Criminal Justice, v. 39, n. 2, pp. 187-205.

HINDS, Lyn; MURPHY, Kristina. (2007), “Public Satisfaction With Police: Using Procedural Justice to Improve Police Legitimacy". Australian \& New Zealand Journal of Crimino$\log y$, v. 40, n. 1, pp. 27-42.

HITLIN, Steven; VAISEY, Stephen. (2013), "The new sociology of morality". Annual Review of Sociology, v. 39, n. 1, pp. 51-69.

JACKSON, Jonathan; BRADFORD, Ben. (2010), "Police legitimacy: a conceptual review". Disponível em: http://ssrn.com/abstract=1684507. Acesso em 02/ago/2017.

JACKSON, Jonathan et al. (2012a), "Why do people comply with the law? Legitimacy and the influence of legal institutions". British Journal of Criminology, v. 52, n. 6, pp. 1051-1071.

JACKSON, Jonathan et al. (2012b), "Policing by consent: understanding the dynamics of police power and legitimacy". ESS Country Specific Topline Results Series, v. 1, pp. 3-13. 
JACKSON, Jonathan et al. (2016), "Truly free consent? Clarifying the nature of police legitimacy". Disponível em: http://dx.doi.org/10.2139/ssrn.2620274. acesso em 02/ ago/2017.

JACKSON, Jonathan; KUHA, Jouni. (2016), “How theory guides measurement: examples from the study of public attitudes toward crime and policing". In: T. S. Bynum; B. M. Huebner (eds.), Handbook on measurement issues in criminology and criminal justice. Nova Jersey: John Wiley.

KENNEDY, Kelvin. (1984), "A critical appraisal of criminal deterrence theory". 88 Dick L. Rev., n. 1, pp. 1-13.

MACQUEEN, Sarah; BRADFORD, Ben. (2015), “Enhancing public trust and police legitimacy during road traffic encounters: results from a randomised controlled trial in Scotland". Journal of Experimental Criminology, v. 11, n. 3, pp. 419-443.

MUNIZ, Jacqueline; PROENÇA JR., Domício. (2014), “Mandato policial”. In: R. S. Lima, J. L. RATTON; R. G. Azevedo (eds.), Crime, Polícia e Justiça no Brasil. São Paulo: Contexto.

MURPHY, Kristina; HINDS, Lyn; FLEMING, Jenny. (2008), “Encouraging public cooperation and support for police". Policing and Society, v. 18, n. 2, pp. 136-155.

MURPHY, Kristina; TYLER, Tom; CURTIS, Amy. (2009), “Nurturing regulatory compliance: is procedural justice effective when people question the legitimacy of the law?". Regulation \& Governance, v. 3, n. 1, pp. 1-26.

OLIVEIRA, Thiago R.; OLIVEIRA, André Rodrigues; ADORNO, Sergio. (2019), "Legitimidade policial: um modelo de mensuração". Revista Brasileira de Ciências Sociais, v. 34, n. 100 , pp. $1-25$.

SUNSHINE, Jason; TYLER, Tom. (2003), "The role of procedural justice and legitimacy in shaping public support for policing". Law and Society Review, v. 37, n. 3, pp. 513-548.

TANKEBE, Justice. (2009), "Public cooperation with the police in Ghana: does procedural fairness matter?". Criminology, v. 47, n. 4, pp. 1265-1293.

(2013), "Viewing things differently: the dimensions of public perceptions of legitimacy". Criminology, v. 51, n. 1, pp. 103-135.

TYLER, Tom. (1990), Why people obey the law: procedural justice, legitimacy and compliance. New Haven: YUP.

. (2003), "Procedural justice, legitimacy and the effective rule of law". Crime and Justice, v. 30, pp. 283-357.

. (2004), "Enhancing police legitimacy". The Annals of the American Academy of Political and Social Science, v. 593, n. 1, pp. 84-99.

. (2009), "Legitimacy and criminal justice: the benefits of self-regulation". Ohio State Journal of Criminal Law, v. 7, n. 1, pp. 307-359.

; JACKSON, Jonathan. (2013), "Future challenges in the study of legitimacy and criminal justice". In: J. Tankebe; A. Liebling (eds.), Legitimacy and criminal justice: an international exploration. Oxford: Oxford University Press. 
Thiago R. Oliveira, André Zanetic, Ariadne Natal

WEBER, Max. (2004), Economia e sociedade: fundamentos da sociologia compreensiva, v. 2. São Paulo: Editora UnB.

WOLFE, Scott et al., "Is the effect of procedural justice on police legitimacy invariant? Testing the generality of procedural justice and competing antecedents of legitimacy". Journal of Quantitative Criminology, v. 32, n. 2, pp. 253-282.

ZANETIC, André. (2017), "Ação institucional, confiança na polícia e legitimidade em São Paulo". Revista Brasileira de Ciências Sociais, v. 32, n. 95, pp. 1-19.

; et al. (2016), "Legitimidade da polícia: segurança pública para além da dissuasão". Civitas - Revista de Ciências Sociais, v. 16, n. 4, pp. 148-173. 


\section{RESUMO}

\section{Preditores e Impactos da Legitimidade Policial: Testando a Teoria da Justeza Procedimental em} São Paulo

Este artigo busca investigar empiricamente os preditores e os impactos da percepção pública de legitimidade policial em São Paulo. O objetivo foi testar o modelo de Tyler a respeito da percepção de justeza procedimental no contexto brasileiro. Utilizamos, assim, dados de um survey representativo de adultos residentes em São Paulo, em 2015. A estratégia analítica adotada envolveu modelagem de equações estruturais para testar o papel mediador dos julgamentos de legitimidade policial entre a expectativa de justeza procedimental por parte da polícia e o comportamento de conformidade legal. Os resultados indicam maior complexidade na mensuração da noção de dever de obedecer no contexto paulistano, em relação ao cenário internacional. A partir de uma análise das respostas espontâneas a respeito da motivação de obediência, sugerimos quatro categorias de legitimidade policial: dever moral de obedecer; desobediência por protesto; obrigação coercitiva; rejeição da autoridade. Essas categorias foram incorporadas no modelo. As duas primeiras, que reconhecem a autoridade policial como legítima, estão associadas à percepção de justeza procedimental e são preditoras significativas do respeito às leis. As outras categorias, que não reconhecem a polícia como legítima, não. Por fim, discutimos algumas considerações a respeito das implicações para as políticas de segurança pública no Brasil.

Palavras-chave: legitimidade policial; obediência às leis; justeza procedimental; análise de survey; modelo de equações estruturais

\section{ABSTRACT \\ Predictors and Impacts of Police Legitimacy: Testing the Theory of Procedural Fairness in São Paulo}

This paper seeks to empirically investigate the predictors and the impacts of public perceptions of police legitimacy in São Paulo. The objective was to test Tyler's model regarding the perception of procedural fairness in the Brazilian context. Thus, we used data from a representative survey of adults living in São Paulo in 2015. The analytical strategy adopted involved modeling structural equations to test the mediating role of police legitimacy judgments between the expectation of procedural fairness in police actions and legal compliance behavior. The results indicate a greater complexity in measuring the notion of duty to obey in the São Paulo context, in relation to the international scenario. Considering an analysis of spontaneous responses regarding the motivation of obedience, we suggest four categories of police legitimacy: moral duty to obey; disobedience 
through protest; coercive obligation; rejection of authority. These categories were incorporated into the model. The first two, which recognize police authority as legitimate, are associated with the perception of procedural fairness and are significative predictors of respect for the law. The others, who do not recognize the police as legitimate, are not. Finally, we discuss some considerations regarding the implications of these findings for public security policies in Brazil.

Keywords: police legitimacy; obedience to the law; procedural fairness; survey analysis; structural equation model

\section{RÉSUMÉ \\ Prédicteurs et Impacts de la Légitimité de la Police: Mise à L'épreuve de la Théorie de L'équité Procédurale à São Paulo}

Cet article cherche à étudier de manière empirique les facteurs prédictifs et les impacts de la perception publique de la légitimité de la police à São Paulo. L'objectif était de tester le modèle de Tyler en ce qui concerne la perception de l'équité procédurale dans le contexte brésilien. Ainsi, nous avons utilisé les données d'une enquête représentative auprès d'adultes vivant à São Paulo en 2015. La stratégie analytique adoptée a consisté à modéliser des équations structurelles pour tester le rôle médiateur des jugements de légitimité de la police entre les attentes de la police en matière d'équité procédurale et comportement de conformité légale. Les résultats indiquent une plus grande complexité dans la mesure de la notion d'obligation d'obéir dans le contexte de São Paulo, par rapport au scénario international. À partir d'une analyse des réponses spontanées à la motivation d'obéissance, nous suggérons quatre catégories de légitimité de la police: le devoir moral d'obéir; la désobéissance pour la protestation; obligation coercitive; rejet de l'autorité. Ces catégories ont été intégrées au modèle. Les deux premiers, qui reconnaissent l'autorité de la police comme légitime, sont associés à la perception de l'équité procédurale et sont des prédicteurs importants du respect de la loi. Les autres catégories, qui ne reconnaissent pas la police comme légitime, ne le font pas. Enfin, nous discutons de quelques considérations concernant les implications pour les politiques de sécurité publique au Brésil.

MOTS-CLÉS: légitimité de la police; obéissance aux lois; équité procédurale; analyse d'enquête; modèle d'équation structurelle 


\section{RESUMEN \\ Predictores e Impactos de la Legitimidad Policial: Probando la Teoría de la Justicia Procesal en São Paulo}

Este artículo busca investigar empíricamente los predictores y los impactos de la percepción pública de legitimidad policial en São Paulo. El objetivo es probar el modelo de Tyler respecto de la percepción de justicia procesal en el contexto brasilero. Utilizamos, así, datos de una encuesta representativa de adultos residentes en São Paulo aplicada en 2015. La estrategia analítica adoptada involucra el modelaje de ecuaciones estructurales para probar el papel mediador de los juicios de legitimidad policial entre la expectativa de justicia procesal por parte de la policía y el comportamiento de conformidad legal. Los resultados indican una mayor complejidad en la medición de la noción del deber de obedecer en el contexto paulistano, en relación al escenario internacional. A partir de un análisis de las respuestas espontáneas respecto de la motivación de obediencia, sugerimos cuatro categorías de legitimidad policial: deber moral de obedecer; desobediencia por protesta; obligación coercitiva; rechazo de la autoridad. Esas categorías fueron incorporadas en el modelo. Las dos primeras, que reconocen la autoridad policial como legítima, están asociadas a la percepción de justicia procesal y son predictores significativos de respeto a las leyes. La otras categorías, que no reconocen la policía como legítima, no. Finalmente, discutimos algunas consideraciones respecto de las implicaciones para las políticas de seguridad pública en Brasil.

Palabras clave: legitimidad policial; obediencia a las leyes; justicia procesal; análisis de encuesta; modelo de ecuaciones estructurales 